\title{
The Effect of Anthropomorphic Mascot on The Purchasing Intention of Consumers: An Experimental Study ${ }^{1}$
}

\author{
Kadir DELIGGÖZ (https://orcid.org/0000-0003-3247-9223), Atatürk University, Turkey; \\ kadir.deligoz@atauni.edu.tr \\ Sevtap ÜNAL (https://orcid.org/0000-0002-3227-0756), İzmir Katip Çelebi University, Turkey; \\ sevtap.unal@ikcu.edu.tr

\section{Tüketicilerin Satın Alma Niyetlerinde Antropomorfik Maskotun Etkisi: Deneysel Bir Çalışma²}

\begin{abstract}
Anthropomorphism, the process of attributing human physical or mental characteristics to living beings, such as plants and animals, and inanimate beings, such as objects, or events, is one of the most effective ways to connect consumers and businesses. Anthropomorphism creates an opportunity for consumers to identify themselves with businesses, products, or services. This study explores the effect of anthropomorphic mascots on the purchasing intention of consumers in an experimental layout. The study, for which data was collected through surveys, was conducted in Erzurum, Turkey. The study results conclude that the anthropomorphic mascot positively affects consumers' purchasing intention towards brands. In addition, brand image, brand value, identity, personality, experience, and engagement towards brands using anthropomorphic mascots positively affect purchasing intent.
\end{abstract}

Keywords

Animism, Anthropomorphism, Brand, Mascot, Purchasing Intention.

JEL Classification Codes : $\quad$ M30, M31, M37.

Öz

Müşteriler, ürün veya hizmetleri kendileriyle özdeşleştirmek için evrensel bir eğilim içerisindedirler. Bu nedenle insana ait özelliklerin diğer varlıklara atfedilmesi olan antropomorfizm, tüketicilerin işletme, ürün veya hizmetler ile kendisini özdeşleştirmesi için bir firsat yaratmaktadır. Bu çalışmada, tüketicilerin satın alma niyetlerinde antropomorfik maskotun etkisi deneysel serim şeklinde araştırılmıştır. Verileri anket yoluyla toplanan çalışma Erzurum ili merkez ilçelerinde yapılmıştır. Araştırma sonuçlarına göre tüketicilerin markalara yönelik satın alma niyetlerinde antropomorfik maskotun olumlu etkisi olduğu sonucuna varılmıştır. Ayrıca antropomorfik maskot kullanan markalara yönelik marka imajı, marka değeri, marka kimliği, marka kişiliği, marka deneyimi ve marka ilginliğinin satın alma niyeti üzerinde olumlu etkiye sahip olduğu sonucuna varılmıştır.

1 This study is derived from the doctoral dissertation of Kadir Deligoz entitled "The effect of anthropomorphic mascot of consumers' purchase intention towards brands: An experimental study", supervised by Sevtap UNAL in Erzurum Ataturk University, Institute of Social Sciences, 21/12/2018. The authors highly appreciate their contribution to the Ataturk University Methodology Office. Also, we would like to thank Assoc.Prof.Dr. Yasemin Taş and Asst.Prof.Dr. Mine Yazıcl.

2 Bu çalışma Kadir Deligöz'ün 21/12/2018 tarihinde Erzurum Atatürk Üniversitesi Sosyal Bilimler Enstitüsü'nde Sevtap ÜNAL danışmanlı̆ıında savunulan "Tüketicilerin markalara yönelik satın alma niyetlerinde antropomorfik maskotun etkisi: Deneysel bir çalışma" başlıklı doktora tezine dayanarak hazırlanmışstır. 
Anahtar Sözcükler $\quad$ : Animizm, Antropomorfizm, Marka, Maskot, Satın Alma Niyeti.

\section{Introduction}

Animism believes that non-human beings have a soul (quoting from Proctor, 2018: 230). The effect this belief creates on humans is defined as anthropomorphism. Anthropomorphism is the process of attributing human physical or mental characteristics to living beings, such as plants and animals, and inanimate beings, such as objects or events. Before anthropomorphism, products, brands, and services were only represented as objective beings and considered abstract beings in the minds of consumers and perceived by them. Through anthropomorphism, brands provide characters that can move, think and feel. Businesses can transfer their emotions, thoughts, and personalities to the consumers through anthropomorphism and be differentiated in this way (Guthrie, 1997: 134).

In post-modern times, consumers demand much more than products or services from businesses. For this reason, from the point of view of businesses, they need to achieve much more than the wishes and needs of the consumers. In this context, using an anthropomorphic brand mascot provides various strategies for businesses to connect with consumers and maintain their existing connections. Using an anthropomorphic brand mascot, the businesses aim to achieve a competitive advantage and maintain the existing competitive power. Today, many global businesses use an anthropomorphic brand mascot.

The concept of anthropomorphism has been receiving a lot of attention in the last decade. In the literature on anthropomorphism and brand anthropomorphism, Delbaere et al. (2011) noted that the product's image in advertising representing a human feature could trigger anthropomorphism and increase brand appreciation (quoted from Aggarwal \& McGill, 2012). May and Monga (2014) noted that anthropomorphism tends to cause people to spend time with mental states similar to themselves, reduce consumer patience, and affect consumers' purchasing decisions. In addition to these studies regarding consumers' attribution of human traits to inanimate beings, De Chernatony (1999) studied the relationship between brand identity and celebrity, Park et al. (1986) studied consumer emotions, and Fournier (1998) studied consumer behaviour. Fournier (1998) stated that consumers visualize the products in their minds and form a relationship with them, connect with the brands, leave them and sometimes even distance themselves from them (Hogg, 1998; Lee et al., 2009).

This study tries to determine the effect of the anthropomorphic mascot on the purchasing intents of the consumers towards brands through an experimental study. Experimental layout is mainly the most robust method used to measure the effect of anthropomorphic brand mascots. Therefore, an experimental layout is used in the application section of this study. The study tries to measure using a concrete inanimate being (anthropomorphic brand mascot) on hotel businesses from accommodation management that have abstraction (intangibleness), one of the most important characteristics of service 
marketing. In addition, the study tries to determine the effect of brand image, brand value, brand identity, brand personality, brand experience, and brand engagement towards brands using anthropomorphic mascots on purchasing intent. The study examines the effect of using anthropomorphic brand mascots on consumers' brand concepts and purchasing intents. To this end, variables of purchasing intention, brand image, brand value, brand identity, brand personality, brand experience, and brand engagement were included in the study. Within the scope of the study, experiments and surveys were conducted with consumers aged 18 and older living in the provincial centre of Erzurum, one of the central provinces in eastern Turkey.

\section{The Concept of Mascot}

Mascot means an "object believed to bring luck" in Turkish and comes from the French word "Mascotte." A mascot is all human, animal, and inanimate characters that symbolize products and services (Tek, 2004: 29). In its most general definition, a mascot is a living (human, plant, animal) or inanimate (object) being used by businesses to communicate their products or services to consumers (Garretson \& Niedrich, 2004).

The concept of mascot appears in various forms in the literature. For example, commercial character (Kirkpatrick, 1986; Mizerski, 1997; Phillips, 1996; Phillips \& Gyoerick, 1999), spokes-character (Callcott \& Alvey, 1991; Callcott \& Lee, 1995; Peirce \& Mcbride, 1999; Stafford et al., 2002; Garredson \& Niedrich, 2004; Neeley \& Schuman, 2004; Dotz \& Husain, 2003), animated character (Auken \& Lonial, 1985) and mascot (Tek, 2004; Baglole, 2002; Odabaşı, 2003) use this concept (Halıçınarlı, 2008: 44). The term "mascot" is used in our study to ensure integrity.

There are three types of relationships between the brands and the mascots. The first is the metaphorical relationship where the mascot embodies the brand. For example, Mr. Peanut becomes the peanut character and embodies the brand in the eyes of consumers. The second is the metonomic relationship, where the mascot abstracts the brand. For example, mascots such as the Marlboro Man, which is the mascot of the Marlboro cigarettes, are not embodied but only depicted in pictures.

Moreover, the third is a superficial relationship. In this relationship, the consumer knows the mascot but has difficulty associating it with the brand. Fido Dido (7-Up), Juan Sheet (Bounty), and Nicole Kidman (Channel) are examples of this type of mascot (Brown, 2011).

Mascots, the most important marketing communication tools businesses use to connect with consumers, should be easily recognized. For this reason, the mascot should be identified with the brand, product, or service and have a relationship between them. For example, they are using a traditional and modest mascot while designing a mascot related to a technological product that confuses consumers. A conflict among the brand, product or 
service, and mascot triangle can lead to irreparable damages for businesses (John, 1999: $183)$.

\section{The Concept of Anthropomorphism}

The term animism is generally used to refer to the attribution of intentional action and a general concept of "life" to objects and natural phenomena. Anthropomorphism is more specifically the attribution of human mental states or affects to non-humans. These two concepts are distinct and, at the same time, strictly connected. We could say that animism is a weaker form of anthropomorphism. However, when humans attribute life to non-humans, they often also attribute human mental and affective states (Airenti, 2018: 2).

Anthropomorphism is the attribution of human physical and mental characteristics to non-human beings or events. It is a phenomenon that many people often encounter in their daily lives (Haigood, 1999: 149). It has been noted that throughout history, people tend to see non-human beings (animals, plants, inanimate beings, or objects) as human beings. Darwin (1872), Feuerbach (1873), Freud (1930), and Hume (1956) studied these tendencies and examined people's tendencies to anthropomorphism, what anthropomorphism represents, and suggested that anthropomorphism affects every aspect of life, from religious belief to marketing practices (Epley et al., 2007: 95).

People usually look for and see human characteristics in natural beings (for example, seeing a human face when looking at the clouds or the mountains). Already when they are 15-month-old, children engage with mothers in reciprocal imitation of pretence actions, and mothers' imitation predicts children's pretending (Markova \& Legerstee, 2015: 12). David Hume (1956) suggested that people have a universal tendency to see all beings as themselves throughout history and noted that people try to find faces on the moon, armies in the clouds, and terrible men on the rocks. In addition to human shapes, human emotions are attributed to inanimate beings. For example, they liken the relationship between male and female birds to newlywed couples' flirtation. Sometimes people even consider their stuff, for example, cars or computers, their best friend, name them, react to them when they are angry, or try to convince them (Aggarwal \& McGill, 2007: 468).

Researchers noted that highlighting human-like characteristics in products or services is a commonly used technique to increase product or service appreciation (Aaker, 1997; Brown, 2010; DiSalvio \& Gemperle, 2003). Anthropomorphic brand mascots relax and assure the consumers before, during, and after purchasing (Shapiro, 2004). As consumers' hesitation about trust affects their purchases, this effect of anthropomorphic brand mascots is highly significant. In infancy, a fundamental feature of anthropomorphism is that two possible roles are attributed to the actors in these interactions. One character may cooperate with or obstacle to the other's supposed goals (Tomasello \& Vaish, 2013: 240).

Guthrie (1993) proposed a cognitive and perceptual strategy that claims that the world is like a human being. Accordingly, the world is a living being, and all objects can be 
anthropomorphized. The demand for the product can be maximized through anthropomorphism by adding additional characteristics to the already existing characteristics of the product (quoted from Rosch et al., 1976: 382). Anthropomorphism occurs in three ways according to Guthrie (1993): partial anthropomorphism (seeing inanimate beings or events as having some human characteristics, but not as human as a whole), incidental anthropomorphism (incidentally likening inanimate beings or events to humans), and complete anthropomorphism (seeing inanimate beings or events as a natural person in a way that all human characteristics are attributed to).

DiSalvio et al. (2005) stated that anthropomorphism occurs in four different ways. These include structural anthropomorphism (imitating human body, shape, structure, or functioning), signal anthropomorphism (focus on gestures, facial expressions, or hand-arm movements that humans use for communication), characteristic anthropomorphism (imitating human characteristics or functions), and conscious anthropomorphism (imitating human thought, intention, or questioning capacity).

Suggesting that people have anthropomorphic tendencies on products, animals, and mythological beings, Callcott and Lee (1995) stated that this anthropomorphism occurs in four different ways. These include highly anthropomorphized characters (which includes all characteristics of humans), well-anthropomorphized characters (which only includes talks and gestures), less anthropomorphized characters (which have a personality that only allows the consumer to connect to it), and slightly anthropomorphized characters (which only uses a limited set of words).

In addition to the rating by Callcott and Lee (1995), Khogeer (2013) also graded the level of anthropomorphism in a range ranging from low to high. From the highest to the lowest, these include limited words, storytelling, adding facial features such as mouth and nose, adding limbs such as arm and leg, improved posture, applying to clothing, adding personality, increased emotions, human features and being human, which is the highest level. For example, the design of the Michelin human depends on a stack of tires with the addition of limbs and a better posture. However, it has never uttered any word. Nevertheless, it is considered at a higher level than many anthropomorphic mascots using words.

Epley et al. (2007) noted that three motivating elements increase or decrease consumers' anthropomorphization. These are sociality motivation, affecting motivation, and psychological motivation. The sociality motivation is based on the desire to establish socials relations with other people as a human need. If people are deprived of social relations, they tend to anthropomorphize even non-human beings such as robots. This tendency compensates for the lack of social support and feelings of loneliness (Epley et al., 2007: 143).

The effecting motivation is a result of people's desire to understand, predict and control their environment. People often want to avoid uncertainty in their daily lives and continue their lives in a planned manner. The effecting motivation supports 
anthropomorphism in this regard. Because people can eliminate the uncertainties around them by giving meaning to inanimate beings. People can easily access everything about inanimate beings or objects and have a sense of control over them. This way, anthropomorphism helps people satisfy their need to predict and control their environment (Gallese \& Goldman, 1998; Meltzoff, 2007; Nickerson, 1999).

People use behavioural observations, intuitive inferences, and verbal reports to interpret the information they have acquired throughout their lives. Therefore, people's inferences about inanimate beings and events are not only the result of their actions. When making inferences about humans, plants, animals, and inanimate beings, people observe inanimate beings, make perceptual inferences about inanimate beings, and finally make use of other information about inanimate beings. Psychological motivation includes information about inanimate beings or objects in people's anthropomorphism tendencies (Higgins, 1996). This information consists of observations, intuitive inferences, and other information on the anthropomorphized entity (Epley et al., 2007: 868).

\section{Significance and Objective of the Study}

Anthropomorphic mascots started finding a place in the literature during the $2000 \mathrm{~s}$ in Turkey and 1990s abroad. However, anthropomorphic mascots at the level of brands are a reasonably new concept, and the number of brands using anthropomorphic mascots is deficient in Turkey. Nevertheless, the use of anthropomorphic mascots is becoming widespread both in Turkey and abroad. Businesses try to provide significant advantages in the competition that are hard to imitate by developing strategies using anthropomorphic mascots.

When the concept of anthropomorphic mascots is viewed from a theoretical point of view, there are many questions to be answered as the concept is new in the literature. Studies on the con of anthropomorphic mascots have significantly contributed to the literature. However, these contributions are limited to specific groups of products and the general definition of the concept. Therefore, the literature on the subject needs to be supported and enriched.

Anthropomorphism makes each concept add value to the other by containing them within. The study examines consumers' relationship with each concept for brands using anthropomorphic brand mascots and contributes to businesses and literature on this issue.

This study examines the anthropomorphic mascot's effect on the consumers' purchasing intentions regarding hotel management from accommodation services. The most important reason for addressing hotel management is that the concept of abstraction (intangibleness), which is one of the features of service marketing, is embodied by the designed anthropomorphic brand mascot. Thus, the abstract features of the service are embodied. 
The majority of the current hotel businesses involved in service marketing do not use anthropomorphic mascots. Supporting hotel management, abstract, with a concrete mascot, will help both subsequent work and practitioners. Thus, we aim to contribute to both practitioners and the literature.

The primary aim of this study is to determine the effect of anthropomorphic mascots on the purchasing intention of consumers aged 18 and older in Erzurum towards the brands. Hotel business and an anthropomorphic mascot were designed for the experimental study. The study has determined sub-goals as well as the main aim. These are to determine the effect of (1) brand image, (2) brand value, (3) brand identity, (4) brand personality, (5) brand experience, and (6) brand engagement in the purchasing intention towards brands using anthropomorphic mascots.

The scope of the study is limited in terms of target audience characteristics and the number of subjects considering the time and cost factors. Therefore, the scope of the study consists of consumers aged 18 and older living in the central district of the Erzurum province, one of the major provinces in eastern Turkey. The study was conducted on hotel services within the scope of service marketing.

\subsection{Hypotheses}

The aim of the study developed the following hypotheses.

$H_{1}$ : Anthropomorphic brand mascots positively influence consumer purchasing intent.

$\mathrm{H}_{2}$ : Brand image for brands using anthropomorphic mascots has a positive effect on purchasing intent.

$H_{3}$ : Brand value for brands using anthropomorphic mascots has a positive effect on purchasing intent.

$\mathrm{H}_{4}$ : Brand identity for brands using anthropomorphic mascots has a positive effect on purchasing intent.

$H_{5}$ : Brand personality for brands using anthropomorphic mascots has a positive effect on purchasing intent.

$H_{6}$ : Brand experience for brands using anthropomorphic mascots has a positive effect on purchasing intent.

$H_{7}$ : Brand engagement for brands using anthropomorphic mascots has a positive effect on purchasing intent.

\subsection{Methodology}

The quantitative research methods used the experimental method to examine the cause-and-effect relationship between the study variables. The Pretest - Posttest design with the Non-Random Control Group from the experimental research types was applied in the study. 
In the pretest and posttest, measurement-based research with a control group, the dependent variable in both groups is subjected to measurement before the experiment. Only the independent variable is added to the experimental group. After a certain period, dependent variables in the experimental group are measured (Gegez, 2010: 159). The dependent variable of our study is the purchasing intention, and the independent variable is the anthropomorphic brand mascot.

The important condition of the pretest is that the control group and the experimental group show similar purchasing intent. As the effect of anthropomorphic mascot on the purchasing intention of consumers towards brands is measured in our study, EG $(01)=\mathrm{CG}$ (0) (EG; experimental group - CG; control group). Therefore, a total of $\mathrm{EG}=50$ and $\mathrm{CG}=50$ subject consumers reached $\mathrm{EG}=30$, and $\mathrm{CG}=30$ subject consumers complying with the specified rule participated in the application. In addition, as it is believed that many external factors will affect both groups until the posttest measurement is performed, there was a oneday break between pretest and posttest.

\subsection{Data Collection Tools}

The data were collected using the face-to-face survey technique. 4 groups of questions were included in the survey form. The questions in the first group were prepared to determine the purchasing intention of the respondents. A 14-item "purchasing intention" scale designed by Chang and Liu (2009) and Ostrom (1969) was used to measure purchasing intentions of the participants. The scale was translated into Turkish by linguists, and the translations of the statements were shown to the experts in the Turkish/English language, and their approval was obtained. As a result of the reliability analysis, it was found that the Cronbach's Alpha value of the control group of the purchasing intention scale was $(\alpha)=.715$, and the Cronbach's Alpha value for the experimental group was $(\alpha)=.733$. This value is $\geq 0.7$ indicates that the scale's internal consistency is good (DeVellis, 2016; George \& Mallery, 2003; Kline, 2000).

The questions in the second group include the fundamental concepts regarding the brand. These questions were prepared to determine the brand images of brands using anthropomorphic mascots, the brand value of brands using anthropomorphic mascots, the brand identity of brands using anthropomorphic mascots, the brand personality of brands using anthropomorphic mascots, the brand experience of brands using anthropomorphic mascots, the brand engagement of brands using anthropomorphic mascots.

To measure brand image, the 11-item "Brand Image Perception" scale of Özüpek and Diker (2013), who adapted the items Aaker (1997) Sung and Kim (2010) used in their studies into Turkish, was used. The Cronbach's alpha value of the brand image was found to be 0.77 in this study.

To measure brand value, different scales consisting of 12 items were used to measure four different dimensions of brand value according to Aaker's (1991) model. The scale 
developed by Kim et al. (2003) was used for brand loyalty variables; the scale developed by Baldauf et al. (2003) was used for perceived quality variables; the scale developed by Kim et al. (2003) was used for brand awareness variables; the scale developed by Kim et al. (2003) was used for brand association variables. The scales were translated by expert linguists within the scope of this study, from English to Turkish. The Cronbach's alpha value of the brand value was found to be 0.89 in this study.

The 3-item "Brand Identity" scale designed by Coleman (2011) was used to measure brand identity. Expert linguists translated the scales, and they were translated from English to Turkish. The Cronbach's alpha value of the brand image was found to be 0.83 in this study.

To measure brand experience, the 10-item "Brand Experience" scale designed by Brakus, Schmitt, and Zarantonello (2009) was used. Expert linguists translated the scales from English to Turkish. The Cronbach's alpha value of the brand image was found to be 0.91 in this study.

The 6-item "Brand Engagement" scale designed by Fung So, King, Sparks (2014) was used to measure brand engagement. Expert linguists translated the scales from English to Turkish. The Cronbach's alpha value of the brand image was found to be 0.96 in this study.

The statements in the second group were prepared according to the five-point Likert scale (1: Strongly disagree, 2: Disagree, 3: Neither agree nor disagree, 4: Agree, and 5: Strongly agree).

The questions of the third group measure the brand personality of the brands using anthropomorphic mascots. To measure brand personality, the 24-variable "Brand Personality" scale, which was designed and adapted to Turkey by Aksoy and Özsomer (2007), was used. The statements in the third group were prepared according to the fivepoint Likert scale (1: Not at all, 2: Partially defines, 3: Moderately defines, 4: Mostly defines, and 5: Totally defines). The Cronbach's alpha value of the brand image was found to be 0.89 in this study.

The questions in the fourth group were designed to determine the demographic characteristics of the respondents, such as gender, age, educational background, professional groups, and income level.

\subsection{Sample}

To minimize random assignment subject selection internal and external validity threats in the Non-Incidental Control Group Pretest - Posttest application, random assignment (unbiased assignment) subject selection was made in our study, as it is the most appropriate choice. The participants of the study consist of consumers aged 18 and older 
living in the central district of the Erzurum province, one of the major provinces in eastern Turkey. Table 1 shows the demographic information about the participants.

Table: 1

Demographic Characteristics of the Participants

\begin{tabular}{|c|c|c|c|c|c|}
\hline & & \multicolumn{2}{|c|}{ Control Group } & \multicolumn{2}{|c|}{ Experimental Group } \\
\hline & & Frequency (f) & Percentage (\%) & Frequency (f) & Percentage (\%) \\
\hline \multirow{2}{*}{ Sex } & Female & 12 & 40 & 11 & 36.7 \\
\hline & Male & 18 & 60 & 19 & 63.3 \\
\hline \multirow{4}{*}{ Age } & $18-25$ & 11 & 36.7 & 8 & 26.7 \\
\hline & $26-33$ & 11 & 36.7 & 12 & 40 \\
\hline & $34-41$ & 7 & 23.3 & 10 & 33.3 \\
\hline & $42-49$ & 1 & 3.3 & - & - \\
\hline \multirow{4}{*}{ Educational Status } & Secondary school & 3 & 10 & 2 & 6.7 \\
\hline & Associate Degree & 6 & 20 & 2 & 6.7 \\
\hline & University & 13 & 43.3 & 20 & 66.7 \\
\hline & Master's Degree/Doctorate & 8 & 26.7 & 6 & 20 \\
\hline \multirow{5}{*}{ Professional Groups } & Student & 9 & 30 & 9 & 30 \\
\hline & Office worker & 9 & 30 & 7 & 23.3 \\
\hline & Self-employed & 1 & 3.3 & 1 & 3.3 \\
\hline & Private Sector Employee & 7 & 23.3 & 9 & 30 \\
\hline & Other & 4 & 13.3 & 4 & 13.3 \\
\hline \multirow{7}{*}{ Income Level } & $€ 1000$ or less & 5 & 16.7 & 8 & 26.7 \\
\hline & $£ 1001-2000$ & 7 & 23.3 & 1 & 3.3 \\
\hline & $€ 2001-3000$ & 6 & 20 & 3 & 10 \\
\hline & $€ 3001-4000$ & 6 & 20 & 11 & 36.7 \\
\hline & $£ 4001-5000$ & 3 & 10 & 5 & 16.7 \\
\hline & $£ 5001-6000$ & 2 & 6.7 & 2 & 6.7 \\
\hline & $£ 6001-7000$ & 1 & 3.3 & - & - \\
\hline
\end{tabular}

By these results, it is seen that the majority of the control group respondents are men and women between the ages of 18-33, who have received a university education and are still studying, primarily students and civil servants with an income of 1001-2000 TL. It is seen that the majority of the experimental group respondents are men and women between the ages of 26-33, who have received a university education and are still studying, primarily students and private sector employees with an income of 3001-4000 TL.

\subsubsection{Design of the Anthropomorphic Brand Mascot and the Commercial Film}

The study was conducted on hotel businesses which are one of the most important markets of the service industry. The study researchers named the hotel they designed as SIS Hotel, Sustainable, Intelligent, and Smart. SIS Hotel is a technological hotel trying to implement the concept of sustainability, where all of the workers are robots. SIS Hotel is a type of hotel that consumes less energy and water, reduces $\mathrm{CO}_{2}$ emissions, has a positive impact on global climate change, is built with environmentally friendly local and recyclable materials, and shows its investor's social and environmental responsibility.

Due to the principle of abstraction (intangibleness), which is the most important feature of the service industry, a concrete anthropomorphic mascot was designed in this industry. The anthropomorphic brand mascot was designed as a robot to create a technological perception. Shortly, more robots will be involved in our daily lives and will be used everywhere. An important aspect of socially interactive robots is the design of 
effective human-robot interaction (HRI) and acceptance. The acceptance of robots by humans is a result of anthropomorphism (Duffy, 2002: 40).

For this reason, in our study, an anthropomorphic brand mascot and SIS Hotel were designed with open-code software "Blender and Maya" programs that enable the modelling (creation) of 3D objects. The mascot was named SISOT (the abbreviation of SIS Hotel) for the anthropomorphic brand mascot to establish an emotional bond with the consumers. Figure 1 shows technological character modelling, and Figure 2 shows the designed anthropomorphic brand mascot.

Figure: 1

Technological Character Modelling Stages

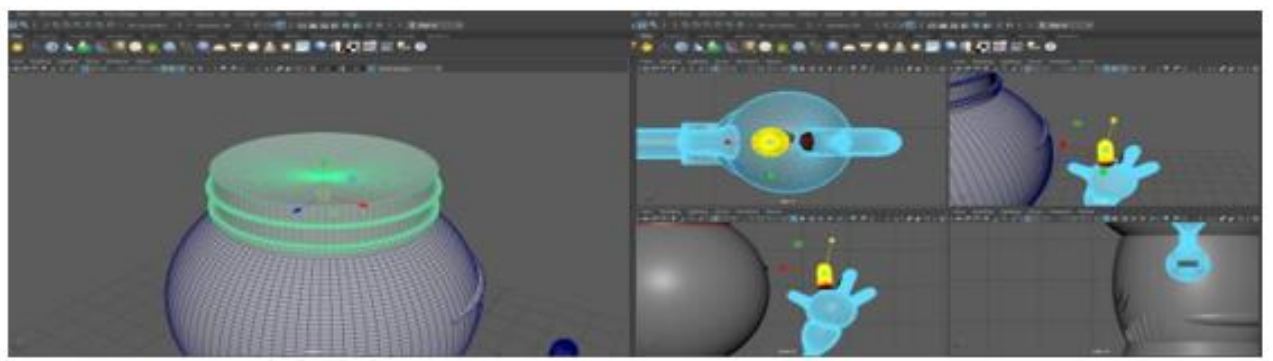

Figure: 2

Designed Anthropomorphic Brand Mascot

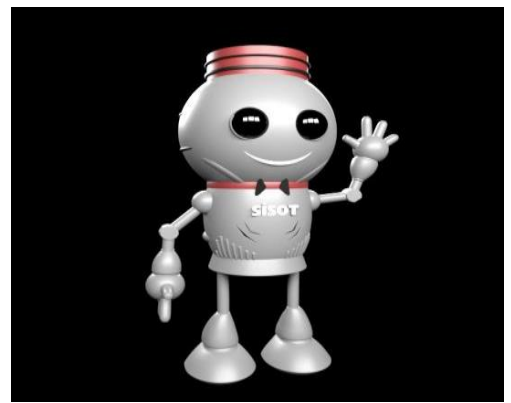

A commercial film involving the anthropomorphic brand mascot SISOT and the SIS Hotel, the application's hotel business, was made for the subjects in the experimental group to watch. Figure 3 shows the images of the design of the commercial film, and Figure 4 shows the images from the commercial film. 
Figure: 3

\section{Stages of Commercial Film Design}

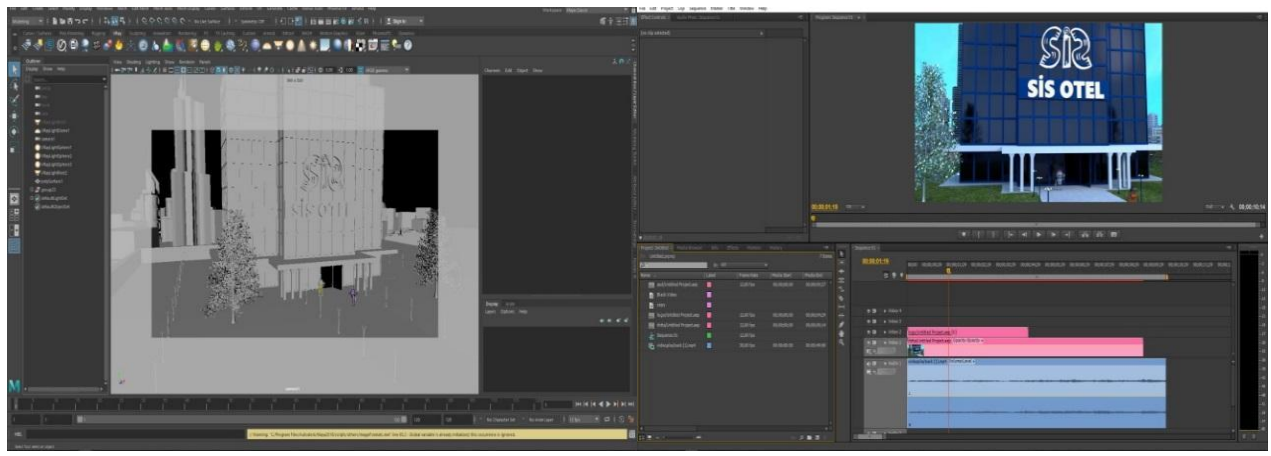

Figure: 4

Images from the Designed Commercial Film

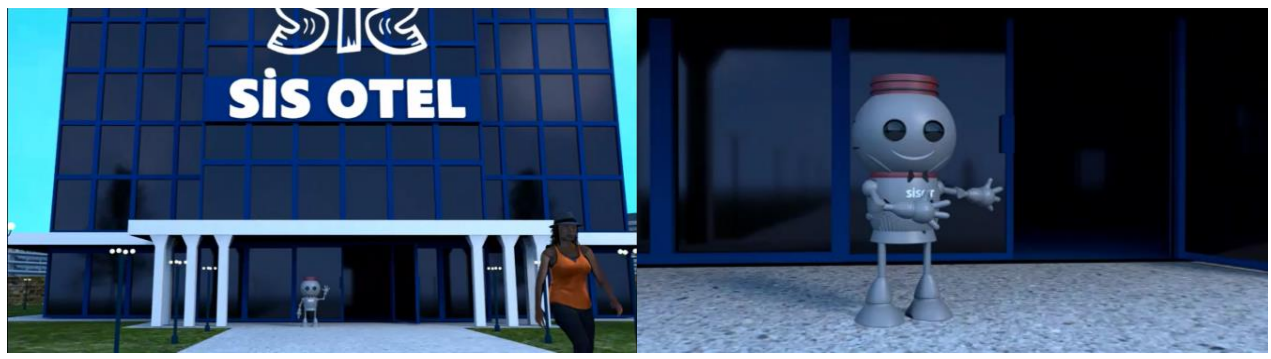

\subsubsection{Validity and Reliability in Experimental Research}

Within the scope of the internal validity in the study, it is not expected that there will be a change in the mental and psychological state of the participants (maturation effect) by keeping the study short with a total of two sessions. In addition, we tried to eliminate the threats to internal validity by setting the time between two sessions today (past effect), not telling subjects what was being measured (test effect), testing the participants individually (effect of the measuring tool), selecting the participants randomly (error in test units), shortening the duration of the experiment (time effect) and choosing the groups with the same number and quality (subject loss) (Keith \& Ben, 1969: 18; Kurtuluş, 2010: 73; Green \& Donald, 1978: 89; Kavak, 2017: 124-126; Campbell \& Stanley, 1963: 175).

Within the scope of external validity, we tried to experiment on the subject who can represent a more significant population (sample effect), ensured that the subjects were unaware of the experiment (the reactivity effect or the effect of expectations), and conducted a pretest in the study (pretest-experimental variable interaction effect) (Kaptan, 1973: 216217; Karasar, 2009: 107, Büyüköztürk, 2001: 9). Reliability can be measured indirectly with the idea that research findings can be repeated, and results can be generalized beyond certain 
conditions. External validity shows the reliability of the study in a sense (Kavak, 2017: 124). We discussed the theoretical background related to the variables and their causal relationships in a detailed manner within the scope of the structural validity (Hair et al., 2003: 302).

We ensured that the control and experimental groups were equivalent independent variable values before the experiment. We applied a non-random control group pretest and posttest design. In addition, the non-random control group pretest and posttest design is sensitive to selection bias that can occur at the stage of determining control and experimental groups. Subject loss is also a threat element affecting the Karasu non-random control group pretest and posttest design. To prevent this, we gave the anthropomorphic brand mascot (SISOT), which was created with a 3D printer, to the participants to participate in the experiment. Thus, we aimed to increase the motivation of participants to participate in the experiment.

\subsubsection{Pre-study and Application of the Experiment}

We conducted a pre-study before applying the experimental design. The advantages of the pre-study are increasing the main experiment's sensitivity through matching, determining whether there is a ceiling effect, testing individuals' views before the experiment conditions, and insight into intergroup comparability. In light of the data collected from the pre-study, we formed the final version of the experimental design.

On November 26, 2018, we conducted a pre-study with the control and experimental groups consisting of 15 subjects. We created the final version of the experimental design by the obtained results.

We carried out this study in a field experiment environment under real-life and internal validity conditions with less researcher control. We conducted the study in two separate sessions, as it was a pretest-posttest design with a non-random control group. In the first session of the experiment conducted on November 28, 2018, we asked 60 participants in the control (30 subjects) and experiment (30 subjects) groups to survey questions separately and collect data.

On November 29, 2018, we informed the participants in the experimental group about the hotel business (SIS Hotel) and the anthropomorphic brand mascot (SISOT). We made them watch the commercial film we prepared. We collected data on participants in the experimental group.

\subsection{Data Analysis}

The collected data were analysed with SPSS.22 program. We used descriptive statistics, regression, and independent samples t-test in the analysis of the data. 


\subsubsection{Descriptive Statistics of Pretest and Posttest Purchasing Intention Variables}

Table 2 shows the mean and standard deviation values of the answers given to the "Purchasing Intention" scale statements directed to the control and experimental groups participants in the first session where the pretest was performed and that session where the posttest was performed.

Table: 2

Descriptive Statistics for Purchasing Intention Variables

\begin{tabular}{|c|c|c|c|c|c|c|c|c|}
\hline & \multicolumn{4}{|c|}{ Pretest } & \multicolumn{4}{c|}{ Posttest } \\
\hline & \multicolumn{2}{|c|}{ Control Group } & Experimental Group & \multicolumn{2}{c|}{ Control Group } & Control Group \\
\hline & Mean & $\begin{array}{c}\text { Standard } \\
\text { Deviation }\end{array}$ & Mean & $\begin{array}{c}\text { Standard } \\
\text { Deviation }\end{array}$ & Mean & $\begin{array}{c}\text { Standard } \\
\text { Deviation }\end{array}$ & Mean & $\begin{array}{c}\text { Standard } \\
\text { Deviation }\end{array}$ \\
\hline Purchasing Intention & 3.61 & 0.46 & 3.61 & 0.44 & 3.61 & 0.46 & 4.23 & 0.71 \\
\hline
\end{tabular}

Participation levels in the statement "... Hotel would be my first choice." which is one of the purchasing intention variables of the control group, are highest with an average of 3.83. "I would recommend ... Hotel to my friends and relatives" is in the second place with an average of 3.80 .

Participation levels in the "... Hotel would be my first choice." statement, which is one of the purchasing intention variables of the experimental group, are highest with an average of 4.23. "I would recommend ... Hotel to my friends and relatives" is in the second place.

\subsubsection{Descriptive Statistics of Study Variables}

Table 3 shows the descriptive statistics of the variables used in the study. The highest average is in the brand engagement variable with 4.46. We can say that the businesses using an anthropomorphic brand mascot try to bridge the consumers by using the brand's features. We can also infer descriptive statistics of study variables that businesses using anthropomorphic brand mascots add a high value to their brands.

Table: 3

\section{Descriptive Statistics for Study Variables}

\begin{tabular}{|l|c|c|}
\hline \multicolumn{1}{|c|}{ Standard Deviation } \\
\hline Brand Image & Mean & 0.71 \\
\hline Brand Value & 4.04 & 0.84 \\
\hline Brand Identity & 4.15 & 0.75 \\
\hline Brand Personality & 4.32 & 1.04 \\
\hline Brand Experience & 4.21 & 0.77 \\
\hline Brand Engagement & 4.36 & 0.69 \\
\hline
\end{tabular}

The statement of "SIS Hotel is a cute brand." has the highest value in the brand image scale with an average of 4.60; The statement of "SIS Hotel is remarkable thanks to the SISOT mascot." has the highest value in the brand value scale with an average of 4.50; however, the statement of "SISOT, the anthropomorphic brand mascot of SIS Hotel, is an 
important part of the hotel's identity." has the highest value in the brand identity scale with an average of 4.47; "Dynamic" statement has the highest value in the brand personality scale with an average of 4.77; the statement of "SIS Hotel and its mascot grabbed my attention." has the highest value in the brand image scale with an average of 4.63 and the statement of "Anything about SIS Hotel grabs my attention." has the highest value in the brand engagement scale with an average of 4.55 .

\subsubsection{Differences Between the Purchasing Intention of the Control Group and Experimental Group Respondents in the Pretest and Posttest Stages}

In the first session where the pretest was applied, we conducted Independent Samples T-Test to examine whether there was a difference between the purchasing intentions of the respondents in the control group and the purchasing intentions of the respondents in the experimental group and the results obtained are shown in Table 2.4.

\section{Table: 4}

Differences Between the Purchasing Intention of the Control Group and Experimental Group Respondents in the Pretest Stage

\begin{tabular}{|c|c|c|c|c|c|}
\hline Variables & Groups & Averages & Standard Deviation & t Value & Significance (2 Way) \\
\hline \multirow{2}{*}{ Purchasing Intention } & Control Group & 3.6167 & 0.46144 & \multirow{2}{*}{0.48} & 0.962 \\
\cline { 2 - 6 } & Experimental Group & 3.6111 & 0.43623 & \\
\hline
\end{tabular}

As shown in Table 4, there was no significant difference between the purchasing intentions of the control group respondents and the purchasing intentions of the experimental group respondents in the pretest. Purchasing intentions of both groups are very close to each other.

At the end of the application, we conducted independent samples t-test to examine whether there was a significant difference between the purchasing intentions of the respondents in the control group and the experimental group, and the results obtained are shown in Table 5.

\section{Table: 5}

Differences Between the Purchasing Intention of the Control Group and Experimental Group Respondents in the Posttest Stage

\begin{tabular}{|c|c|c|c|c|c|}
\hline Variables & Groups & Averages & Standard Deviation & t Value & Significance (2 Way) \\
\hline \multirow{2}{*}{ Purchasing Intention } & Control Group & 3.6167 & 0.46144 & \multirow{2}{*}{-2.976} & 0.002 \\
\cline { 2 - 6 } & Experimental Group & 4.2333 & 0.71331 & \\
\hline
\end{tabular}

As shown in Table 5, there was a significant difference between the purchasing intentions of the control group respondents and the purchasing intentions of the experimental group respondents measured in the posttest. The averages given by the experimental group respondents to their purchasing intentions are higher than those of the control group. The obtained results show that consumers have a higher purchasing intention towards businesses using anthropomorphic brand mascots. 


\subsubsection{The Effect of Brand Image on Purchasing Intention towards Brands Using Anthropomorphic Mascots}

Simple linear regression analysis was applied to see the effect of brand image on purchasing intention towards brands using anthropomorphic mascots. Table 6 shows the results of the analysis.

Table: 6

Regression Coefficients and Anova Test Results for the Effect of Brand Image on Purchasing Intention towards Brands Using Anthropomorphic Mascots

\begin{tabular}{|c|c|c|c|c|c|}
\hline \multirow{3}{*}{ ANOVA Values } & $\mathbf{R}$ & $\mathbf{R}^{2}$ & ${\text { Adjusted } \mathbf{R}^{2}}$ & \multirow{2}{*}{\multicolumn{2}{|c|}{$\frac{\text { Standard Error of Prediction }}{0.5173}$}} \\
\hline & 0.702 & 0.492 & 0.474 & & \\
\hline & Sum of Squares & Degree of Freedom & Mean Square & $\mathbf{F}$ & Significance (p) \\
\hline Regression & 7.262 & 1 & 7.262 & 21.133 & .000 \\
\hline Remainders & 7.494 & 28 & 0.268 & & \\
\hline \multirow[t]{3}{*}{ Total } & 14.756 & 29 & & & \\
\hline & \multicolumn{2}{|c|}{ Non-Standardized Coefficients } & Standardized Coefficients & \multirow{2}{*}{ t value } & \multirow{2}{*}{ Significance (p) } \\
\hline & B & Standard Error & Beta & & \\
\hline Fixed Variate & 0.046 & 0.809 & & 0,057 & 0,955 \\
\hline Brand Image & 1.032 & 0.198 & 0,702 & 5,209 & 0,000 \\
\hline
\end{tabular}

Table 6 shows the regression coefficients used for the regression equation and their significance levels. Brand image has a statistically significant and positive effect on the purchasing intention towards brands using anthropomorphic mascots $(\mathrm{p}<0.05)$. The brand image helped explain $49 \%$ of the variance in purchasing intention towards brands using anthropomorphic mascots. Based on this finding, we can say that brand image significantly contributes to the purchasing intention towards brands using anthropomorphic mascots.

\subsubsection{The Effect of Brand Value on Purchasing Intention towards Brands Using Anthropomorphic Mascots}

Using anthropomorphic mascots, simple linear regression analysis was applied to see the effect of brand value on purchasing intention towards brands. Table 7 shows the results of the analysis.

\section{Table: 7}

Regression Coefficients and Anova Test Results for the Effect of Brand Value on Purchasing Intention towards Brands Using Anthropomorphic Mascots

\begin{tabular}{|c|c|c|c|c|c|}
\hline & $\mathbf{R}$ & $\mathbf{R}^{2}$ & Adjusted R ${ }^{2}$ & \multicolumn{2}{|c|}{ Standard Error of Predictions } \\
\hline & 0.716 & 0.513 & 0.496 & \multicolumn{2}{|r|}{0.50657} \\
\hline ANOVA Values & Sum of Squares & Degree of Freedom & Mean Square & $\mathbf{F}$ & Significance (p) \\
\hline Regression & 7.570 & 1 & 7.570 & 29.501 & .000 \\
\hline Remainders & 7.185 & 28 & 0.257 & & \\
\hline \multirow[t]{3}{*}{ Total } & 14.756 & 29 & & & \\
\hline & \multicolumn{2}{|c|}{ Non-Standardized Coefficients } & Standardized Coefficients & \multirow{2}{*}{ t value } & \multirow{2}{*}{ Significance (p) } \\
\hline & $\mathbf{B}$ & Standard Error & Beta & & \\
\hline Fixed Variate & 0.301 & 0.730 & & 0.412 & 0.683 \\
\hline Brand Value & 0.931 & 0.171 & 0.716 & 5.431 & 0.000 \\
\hline
\end{tabular}

Table 7 shows the regression coefficients used for the regression equation and their significance levels. Brand value (0.716) has a positive effect on the purchasing intention 
towards brands using anthropomorphic mascots $(\mathrm{p}<0.05)$. Brand value explained $51 \%$ of the variance in purchasing intention towards brands using anthropomorphic mascots. Based on this finding, we can say that brand value significantly contributes to the purchasing intention towards brands using anthropomorphic mascots. By these results, " $\mathrm{H}_{3}$ : Brand value for brands using anthropomorphic mascots has a positive effect on the purchasing intent." hypothesis is accepted.

\subsubsection{The Effect of Brand Identity on Purchasing Intention towards Brands Using Anthropomorphic Mascots}

Simple linear regression analysis was applied to see the effect of brand identity on purchasing intention towards brands using anthropomorphic mascots. Table 8 shows the results of the analysis.

Table: 8

Regression Coefficients and Anova Test Results for the Effect of Brand Identity on Purchasing Intention towards Brands Using Anthropomorphic Mascots

\begin{tabular}{|c|c|c|c|c|c|}
\hline & $\mathbf{R}$ & $\mathbf{R}^{2}$ & Adjusted $\mathbf{R}^{2}$ & \multirow{2}{*}{\multicolumn{2}{|c|}{$\frac{\text { Standard Error of Predictions }}{0.59986}$}} \\
\hline & 0.563 & 0.317 & 0.293 & 0.59986 & \\
\hline ANOVA Values & Sum of Squares & Degree of Freedom & Mean Square & $\mathbf{F}$ & Significance (p) \\
\hline Regression & 4.680 & 1 & 4.680 & 13.007 & 0.001 \\
\hline Remainders & 10.075 & 28 & 0.360 & & \\
\hline \multirow[t]{3}{*}{ Total } & 14.756 & 29 & & & \\
\hline & \multicolumn{2}{|c|}{ Non-Standardized Coefficients } & Standardized Coefficients & \multirow{2}{*}{ t value } & \multirow{2}{*}{ Significance (p) } \\
\hline & B & Standard Error & Beta & & \\
\hline Fixed Variate & 1.495 & 0.767 & & 1.948 & 0.62 \\
\hline Brand Identity & 0.624 & 0.173 & 0.563 & 3.607 & 0.001 \\
\hline
\end{tabular}

Table 8 shows the regression coefficients used for the regression equation and their significance. Brand identity (0.563) affects the purchasing intention towards brands using anthropomorphic mascots $(<0.05)$. The variance explained by brand identity in purchasing intention for brands using anthropomorphic mascots is $32 \%$. Based on this finding, we can say that brand identity significantly contributes to the purchasing intention towards brands using anthropomorphic mascots. By these results, " $H_{4}$ : Brand identity for brands using anthropomorphic mascots has a positive effect on the purchasing intent." hypothesis is accepted.

\subsubsection{The Effect of Brand Personality on Purchasing Intention towards Brands Using Anthropomorphic Mascots}

Simple linear regression analysis was applied to see the effect of brand personality on purchasing intention towards brands using anthropomorphic mascots. Table 9 shows the results of the analysis. 


\section{Table: 9}

\section{Regression Coefficients and Anova Test Results for the Effect of Brand Personality on Purchasing Intention towards Brands Using Anthropomorphic Mascots}

\begin{tabular}{|c|c|c|c|c|c|}
\hline & $\mathbf{R}$ & $\mathbf{R}^{2}$ & Adjusted R ${ }^{2}$ & \multicolumn{2}{|c|}{ Standard Error of Predictions } \\
\hline & 0.441 & 0.194 & 0.166 & \multicolumn{2}{|c|}{0.65160} \\
\hline ANOVA Values & Sum of Squares & Degree of Freedom & Mean Square & $\mathbf{F}$ & Significance (p) \\
\hline Regression & 2.867 & 1 & 2.867 & 6.753 & 0.015 \\
\hline Remainders & 11.888 & 28 & 0.425 & & \\
\hline \multirow[t]{3}{*}{ Total } & 14.756 & 29 & & & \\
\hline & \multicolumn{2}{|c|}{ Non-Standardized Coefficients } & Standardized Coefficients & \multirow{2}{*}{ t value } & \multirow{2}{*}{ Significance (p) } \\
\hline & B & Standard Error & Beta & & \\
\hline Fixed Variate & 2.001 & 0.867 & & 2.308 & 0.29 \\
\hline Brand Personality & 0.530 & 0.204 & 0.441 & 2.599 & 0.015 \\
\hline
\end{tabular}

Table 9 shows the regression coefficients used for the regression equation and their significance. Brand personality $(0.441)$ has a positive effect on the purchasing intention towards brands using anthropomorphic mascots, and it is significant at $(\mathrm{p}<0.05)$ level. Based on this finding, we can say that brand personality significantly contributes to the purchasing intention towards brands using anthropomorphic mascots. The variance explained by brand personality in purchasing intention for brands using anthropomorphic mascots is $19 \%$. By these results, " $H_{5}$ : Brand personality for brands using anthropomorphic mascots has a positive effect on the purchasing intent." hypothesis is accepted.

\subsubsection{The Effect of Brand Experience on Purchasing Intention towards Brands Using Anthropomorphic Mascots}

Using anthropomorphic mascots, simple linear regression analysis was applied to see the effect of brand experience on purchasing intention towards brands. Table 10 shows the results of the analysis.

Table: 10

\section{Regression Coefficients and Anova Test Results for the Effect of Brand Experience on Purchasing Intention towards Brands Using Anthropomorphic Mascots}

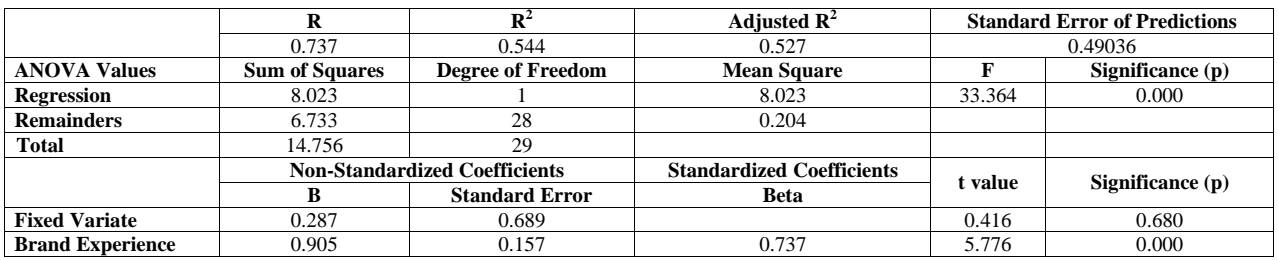

Table 10 shows the regression coefficients used for the regression equation and their significance. Brand experience (0.737) has a positive effect on the purchasing intention towards brands using anthropomorphic mascots $(\mathrm{p}<0.05)$. Based on this finding, we can say that brand identity significantly contributes to the purchasing intention towards brands using anthropomorphic mascots. The variance explained by brand experience in purchasing intention for brands using anthropomorphic mascots is $54 \%$. By these results, " $H_{6}$ : Brand 
experience for brands using anthropomorphic mascots has a positive effect on the purchasing intent." hypothesis is accepted.

\subsubsection{The Effect of Brand Engagement on Purchasing Intention towards Brands Using Anthropomorphic Mascots}

Simple linear regression analysis was applied to see the effect of brand engagement on purchasing intention towards brands using anthropomorphic mascots. Table 11 shows the results of the analysis.

Table: 11

Regression Coefficients and Anova Test Results for the Effect of Brand Engagement on Purchasing Intention towards Brands Using Anthropomorphic Mascots

\begin{tabular}{|c|c|c|c|c|c|}
\hline & $\mathbf{R}$ & $\mathbf{R}^{2}$ & Adjusted R $^{2}$ & \multicolumn{2}{|c|}{ Standard Error of Predictions } \\
\hline & 0.667 & 0.445 & 0.425 & \multicolumn{2}{|c|}{0.54095} \\
\hline ANOVA Values & Sum of Squares & Degree of Freedom & Mean Square & $\mathbf{F}$ & Significance (p) \\
\hline Regression & 6.562 & 1 & 6.562 & 22.425 & 0.000 \\
\hline Remainders & 8.193 & 28 & 0.293 & & \\
\hline \multirow[t]{3}{*}{ Total } & 14.756 & 29 & & & \\
\hline & \multicolumn{2}{|c|}{ Non-Standardized Coefficients } & Standardized Coefficients & \multirow{2}{*}{ t value } & \multirow[b]{2}{*}{ Significance (p) } \\
\hline & B & Standard Error & Beta & & \\
\hline Fixed Variate & 0.881 & 0.715 & & 1.233 & 0.228 \\
\hline Brand Engagement & 0.753 & 0.159 & 0.667 & 4.736 & 0.000 \\
\hline
\end{tabular}

Table 11 shows the regression coefficients used for the regression equation and their significance. Brand identity (0.667) has a positive effect on the purchasing intention towards brands using anthropomorphic mascots $(\mathrm{p}<0.05)$. Based on this finding, we can say that brand engagement significantly contributes to the purchasing intention towards brands using anthropomorphic mascots. The variance explained by brand engagement in purchasing intention for brands using anthropomorphic mascots is $45 \%$. Following these results, " $H_{7}$ : Brand engagement for brands using anthropomorphic mascots has a positive effect on the purchasing intent." hypothesis is accepted.

\section{Conclusion and Recommendations}

In the study, we tested the purchasing intentions of consumers towards brands using an experimental study pattern. The conducted analyses determined that consumers have a higher purchasing intention towards brands using anthropomorphic brand mascots. In addition, we found that all of the brand value, identity, personality, brand experience, and engagement positively predict purchasing intention towards brands using anthropomorphic mascots.

Businesses try to connect with consumers using anthropomorphism in their products or services. This study contributes to the perception of anthropomorphism and brand anthropomorphism both in terms of consumers and businesses. The study discusses numerous ways a business can anthropomorphize its brand and present one of these ways to both businesses and practitioners through experimental design. 
In particular, the lack of literature related to anthropomorphism and brand anthropomorphism in Turkey compensates for this absence. Using an experimental study, the study offers advice on creating a compelling and beloved anthropomorphic brand mascot that consumers will love and embrace for many years. In addition, it also helps businesses discover the levels and determinants of anthropomorphic brand mascots that they can use in the future.

With this study, which we carried out by examining anthropomorphism and brand anthropomorphism in detail, progress was made in understanding the concept of brand anthropomorphism by participating in the current thoughts and the debates in the field of marketing and working in the field of application by businesses. As a part of this progress, we present inferences about the use of anthropomorphism by businesses, the design, development, maintenance, and sustainability of the anthropomorphic brand mascot.

The more the brand, which is introduced to the market by the businesses, conveys the personal human characteristics to the consumers, the more successful it is. Conveying personality to consumers benefits increasing brand loyalty and establishing consumer-brand solid relationships. Some of the studies in the literature address the process of anthropomorphism through the products used by consumers. Cars were used in some studies (Aggarwal \& McGill, 2007), and mobile phones or personal computers (Landwehr et al., 2011) were used in others. We conducted our study on hotel services, an area of accommodation management in the service industry. The study has filled both the literature absence and the application absence in this field. As a result of the studies, we determined that providing products or services with human-like physical characteristics also leads to positive reactions from consumers.

Finally, a technological anthropomorphic mascot design for sustainable hotel business in service marketing is the right choice for businesses and practitioners. Due to the rapid development of technology, consumers tend to have technological products or services. The anthropomorphic brand mascot, designed as a robot for the experimental study, establishes a relationship between the consumer and the product or service. Consumers remember anthropomorphic brand mascots in their experience.

By obtained the results, the following recommendations can be proposed:

Anthropomorphism plays a vital role in the development of brand mascots and drawing the attention of consumers. It has become the centre of communication marketing applications in today's industries. Businesses establish an emotional connection by developing healthy communication with consumers with anthropomorphic brand mascots. Therefore, brand mascots have developed and continue to develop more than ever with the concept of anthropomorphism.

In today's competitive conditions, businesses can acquire a privileged and memorable position with the connection they will establish with the customer. Therefore, it will be 
helpful for businesses to respond to consumers' expectations in their internal world by going beyond their wishes and needs. Businesses will connect with the consumer by reaching the inner world through the anthropomorphic brand mascot that they will design and use. Through this connection, businesses can achieve long-term profitability and competitive advantage. For example, the number of mascots used in hotel management is small, while anthropomorphic mascots are not used. A hotel business using an anthropomorphic mascot to connect with its customers will reach the customer more efficiently. As for customers, the connection with the anthropomorphic brand mascot will make them feel safe and eliminate risk perceptions. In this respect, we can say that the anthropomorphic brand mascot is mutually beneficial for both customers and businesses.

Businesses first need to do R\&D work to design an anthropomorphic mascot, as a mistake at the design stage can lead to irreparable results for businesses. For this reason, anthropomorphic brand mascot design is a costly application for businesses and requires significant infrastructure. However, due to the work to be done, the anthropomorphic brand mascot that can establish a relationship with the consumers will take a leading position in the market by gaining a competitive advantage. Today, many businesses increase brand value financially and from a consumer point of view by using an anthropomorphic brand mascot. Therefore, businesses or practitioners should invest in anthropomorphic mascots.

Because of the features of services, primarily abstraction, consumers have higher perceptions of risk than products. To reduce this risk, the abstract service should be embodied in the minds of the consumers. Anthropomorphic mascots are important for the embodiment of abstract services in the minds of the consumers. Anthropomorphic brand mascots reduce the risks perceived by the consumers and positively impact consumer confidence. However, the process of designing an anthropomorphic brand mascot is fairly complex. A failed design can damage the desired message and, thus, the business image. Therefore, businesses desiring to create an anthropomorphic brand mascot should know and professionally apply the determinants and levels of anthropomorphism, as stated in the literature.

Developing a consistent and integrated self-identity in brand management can be considered the first stage in brand structuring. The second point that forms the basis of the brand structuring is the implementation of this self-identity, the axis. This is the main task of brand communication (Uztuğ, 2003: 66). At this point, anthropomorphic brand mascots can be used.

The study determined that all brand image concepts, value, identity, personality, experience, and engagement effectively purchase intention towards brands using anthropomorphic mascots. For this reason, businesses need to consider the basic brand concepts to achieve consumers' purchasing intentions by considering the model as a whole.

Using an anthropomorphic brand mascot is an innovative strategy. Businesses following and successfully implementing this strategy will be able to attract innovative 
consumers. For this reason, using an anthropomorphic brand mascot as part of innovation will provide advantages for businesses desiring to maintain their presence in the industry.

Using an anthropomorphic mascot can create an advantage in promotion activities. For example, announcing promotion activities of the businesses with a cute anthropomorphic brand mascot will make it easier to communicate with customers, which, in turn, can provide the businesses with advantages in both cost and competition.

This study examines the effect of using an anthropomorphic mascot on consumers' purchasing intention in hotel services in the field of accommodation management. Addressing different products, brands, or services in further studies can help to enrich the literature on the subject.

The anthropomorphic mascot is addressed as an independent variable in the application stage. Future studies can address the anthropomorphic mascot as a tool or moderator.

One of the main branches of science that anthropomorphism involves is psychology. However, very little study has been done on the psychological aspect of anthropomorphism. Therefore, studies on the psychological study of anthropomorphism can be conducted. In future studies, it is recommended that studies be conducted to determine the purchasing intention between different product groups and demographic characteristics for a larger sample.

As previously stated, the literature on anthropomorphism is relatively new, and many questions need to be answered. For example, the effect of anthropomorphism on factors that affect the consumers' decision-making process can be studied. Thus, significant contributions can be made to both the literature and the application of anthropomorphism. In addition, applied research can be conducted on types of consumer anthropomorphism, and a rating map on anthropomorphic brand mascots used in Turkey can be drawn.

The study has some limitations that should be addressed. This study was conducted only on hotel businesses in Turkey. For this reason, the fact that the obtained results can be generalized for this industry but not for the others is a significant limitation. The data collection method chosen in the study causes limitations known as sample bias or selection tendency. In addition, other limitations include sample size and conduction of the study in one province due to time and cost constraints. Analysis techniques used in this study also constitute a limitation.

\section{References}

Aaker, D.A. (1991), Managing Brand Equity, San Francisco: Free Press.

Aaker, J.L. (1997), "Dimensions of Brand Personality”, Journal of Marketing Research, 34, 347356. 
Aggarwal, P. \& A.L. McGill (2007), "Is That Car Smiling at Me? Schema Congruity as A Basis for Evaluating Anthropomorphized Products", Journal of Consumer Research, 34, 468-479.

Aggarwal, P. \& A.L. McGill (2012), "When Brands Seem Human, Do Humans Act Like Brands? Automatic Behavioral Priming Effects of Brand Anthropomorphism", Journal of Consumer Research, 39(2), 307-323.

Airenti, G. (2018), "The Development of Anthropomorphism in Interaction: Intersubjectivity", Imagination, and Theory of Mind. Frontiers in Psychology, 9, 1-13.

Aksoy, L. \& A. Özsomer (2007), “Türkiye'de Marka Kişiliği Oluşturan Boyutlar”, 12. Ulusal Pazarlama Kongresi Bildiriler Kitabı, Sakarya Üniversitesi, 1-14.

Auken, V.S. \& S.C. Lonial (1985), "Children's Perceptions of Human Versus Animate Characters: Assessing Implications for Children's Advertising”, Journal of Advertising, 14 (2), 13-22.

Baglole, J. (2002), "Mascots Are Getting Bigger Role in Corporate Advertising Plans", Wall Street Journal, 239(69), 12.

Baldauf, A. et al. (2003), "Performance Consequences of Brand Equity Management: Evidence from Organizations in The Value Chain", Journal of Product \& Brand Management, 12 (4), 220-236.

Brakus, J.J. et al. (2009), "Brand Experience: What is It? How is It Measured? Does It Affect Loyalty", Journal Of Marketing, 73, 52-68.

Brown, S. (2010), "Where the Wild Brands Are: Some Thoughts on Anthropomorphic Marketing", The Marketing Review, 10, 209-224.

Brown, S. (2011), "It's Alive Inside! A Note on The Prevalence of Personification”, Irish Marketing Review, 21(1/2), 3-11.

Büyüköztürk, Ş. (2001), Deneysel Desenler: Öntest-Sontest, Kontrol Grubu, Desen ve Veri Analizi, Ankara: Pegem Akademi Yayıncilık.

Callcott, M.F. \& P.A. Alvey (1991), “Toons Sell... and sometimes they don't: An advertising spokescharacter typology and exploratory study", in: R. Holman (ed.), Proceedings of the 1991, Conference of The American Academy of Advertising, 43-52.

Callcott, M.F. \& W.-N. Lee (1995), "Establishing the Spokes-Character in Academic Inquiry: Historical Overview and Framework for Definition", Advances in Consumer Research, 22, 144-151.

Campbell, D.T. \& J.C. Stanley (1963), Experimental and Quasi-Experimental Designs for Research, USA: Rand McNally and Company.

Chang, H.-H. \& Y.M. Liu (2009), "The Impact of Brand Equity on Brand Preference and Purchase Intentions in The Service Industries", Service Industries Journal, 29(12), 1687-1706.

Coleman, D.A. (2011), "Service Brand Identity: Definition, Measurement, Dimensionality and Influence on Brand Performance", Unpublished Doctoral Dissertation, Birmingham University.

Darwin, C. (1872), The Expression of Emotions in Man and Animals, London: John Murray.

De Chernatony, L. (2010), "Brand Management Through Narrowing the Gap Between Brand Identity and Brand Reputation", Journal of Marketing Management, 1 (3), 157-179.

Delbaere, M. et al. (2011), "Personification in Advertising”, Journal of Advertising, 40(1), 121-130.

DeVellis, R.F. (2016), Scale Development: Theory and Applications, USA: Sage Company. 
DiSalvio, C. \& F. Gemperle (2003), "From Seduction to Fulfillment: The Use of Anthropomorphic Form in Design. Proceedings of the 2003", New York International Conference on Designing Pleasurable Products and Interfaces, 67-72.

Dotz, W. \& M. Husain (2003), Meet Mr. Product; The Art of the Advertising Character, USA: Chronicle Books.

Duffy, B.R. (2002), “Anthropomorphism and Robotics”, Presented at the Symposium on Animating Expressive Characters of Social Interactions, London: Imperial College.

Epley, N. et al. (2007), “On Seeing Human: A Three-Factor Theory Anthropomorphism”, Psychological Review, 114(4), 864-886.

Feuerbach, L. (2004), The Essence of Religion, Amherst, New York: Prometheus Books, (Original work published 1873).

Fournier, S. (1998), “Consumers and Their Brands: Developing Relationship Theory in Consumer Research", Journal of Consumer Research, 24, 343-373.

Fung So, K.K. et al. (2014), "Customer Engagement with Tourism Brands: Scale Development and Validation”, Journal of Hospitality and Tourism Research, 38(3), 304-329.

Gallese, V. \& A.I. Goldman (1998), "Mirror Neurons and The Simulation Theory of Mind-Reading", Trends in Cognitive Sciences, 2, 493-501.

Garretson, J.A. \& R.W. Niedrich (2004), "Spokes-Characters: Creating Character Trust and Positive Brand Attitudes", Journal of Advertising, 33(2), 25-36.

Gegez, E. (2010), Pazarlama Araştırmaları, İstanbul: Beta Basım Yayım Dağıtım.

George, D. \& P. Mallery (2003), SPSS for Windows Step by Step: A Simple Guide and Reference 11.0 Update, Boston: Allyn \& Bacon.

Green, P.E. \& S.T. Donald (1978), Research for Marketing Decisions, Prentice Hall; Revised Edition.

Guthrie, S. (1997), “Anthropomorphism: A Definition and a Theory”, in: R.W. Mitchell et al.(eds.), Anthropomorphism, Anecdotes, and Animals Albany, New York: State University of New York Press.

Guthrie, S.E. (1993), Faces in the Clouds: A New Theory of Religion, New York: Oxford University Press.

Haigood, T.L. (1999), “The Brand Personality Effect: An Empirical Investigation”, American Marketing Association Conference Proceedings, 10(Winter), 140-149.

Hair, J.F. et al. (2003), Marketing Research: Within a Changing Information Environment, USA: McGraw-Hill Irwin.

Halıçınarlı, Ö. (2008), "Marka İletişiminde Ticari Karakterler: "Vadaa” Worldcard ve "Blue Lion"Post Bank Örnek Olay1", Yayımlanmamış Yüksek Lisans Tezi, Eskişehir Anadolu Üniversitesi.

Higgins, E.T. (1996), "Knowledge Activation: Accessibility, Applicability, and Salience”, in: E.T. Higgins \& A.W. Kruglanski (eds.), Social psychology: Handbook of basic principles, New York: Guilford Press.

Hogg, M.K. (1998), “Anti-Constellations: Exploring the Impact of Negation on Consumption”, Journal Marketing Management, 14, 133-58. 
Hume, D. (1956), The natural history of religion, Stanford, CA: Stanford University Press, (Original work published 1757).

John, D.R. (1999), "Consumer Socialization of Children a Retrospective Look at Twenty-Five Years of Research", Journal of Consumer Research, 26(3), 183-200.

Kaptan, S. (1973), Bilimsel Araştırma Teknikleri: Tez Hazırlama Yolları, Ankara: Rehber Yayınevi.

Karasar, N. (2009), Bilimsel Araştırma Yöntemi, Ankara: Nobel Yayın.

Kavak, B. (2017), Pazarlama ve Pazar Araştırmaları: Tasarım ve Analiz (2. Baskl), Ankara: Detay Yayincilik.

Keith, K. \& M.E. Ben (1969), Experimentation for Marketing Decisions, USA: International Textbook Company.

Khogeer, Y.K. (2013), "Brand Anthropomorphism: The Literary Lives of Marketing Mascots", Doctoral Dissertation, Management School, University of Liverpool.

Kim, H. et al. (2003), "The Effect of Consumer-Based Brand Equity on Firms' Financial Performance", Journal of Consumer Marketing, 20(4), 335-351.

Kirkpatrick, C.A. (1986), "Trade Characters in Promotion Programs”, The Journal of Marketing, 17, 360-371.

Kline, P. (2000), The Handbook of Psychological Testing, London: Routledge.

Kurtuluş, K. (2010), Araştırma Yöntemleri, İstanbul: Türkmen Kitapevi.

Landwehr, J.R. et al. (2011), "It's got the look: The Effect of Friendly and Aggressive 'Facial' Expressions on Product Liking and Sales", Journal of Marketing, 75(3), 132-146.

Lee, M.S.W. et al. (2009), “Anti-Consumption and Brand Avoidance”, Journal of Business Research, 62, 169-180.

Markova, G. \& M. Legerstee (2015), "The Role of Maternal Behavior in Children's Pretense During the Second Year of Life", Cognit. Dev. 34, 3-15.

May, F. \& A. Monga (2014), "When Time Has a Will of Its Own, The Powerless Don't Have the Will to Wait: Anthropomorphism of Time Can Decrease Patience", Journal of Consumer Research, 40, 924-942.

Meltzoff, A.N. (2007), "The "Like Me" Framework for Recognizing and Becoming an Intentional Agent", Acta Psychologica, 124, 26-43.

Mizerski R. (1997), "The Relationship Between Cartoon Trade Character Recognition and Attitude Toward Product Category in Young Children”, Social Marketing Quaterly, 59, 58-70.

Neeley S.M. \& D.W. Schumann (2004), "Using Animated Spokes-Characters in Advertising to Young Children", Journal of Advertising, 33 (3), 7-23.

Nickerson, R.S. (1999), "How We Know and Sometimes Misjudge What Others Know: Imputing One's Own Knowledge to Others", Psychological Bulletin, 125, 737-759.

Odabaşı, Y. (2003), Tüketici Davranışı (2. Basım), İstanbul: Mediacat Yayınları.

Ostrom, T.M. (1969), “The Relationship Between the Affective, Behavioral, And Cognitive Components of Attitude”, Journal of Experimental Social Psychology, 5(1), 10-99.

Özüpek, N.M. \& E. Diker (2013), “İletişim Fakültesi Öğrencilerinin Cep Telefonu Markalarına Yönelik İmaj Algısı: Nokia ve Samsung Örneği”, e-Journal of New World Sciences Academy, NWSA -Humanities, 8(1), 100-120. 
Park, C.W. et al. (1986), “Strategic Brand Concept Image Management”, Journal of Marketing, 50, 135-145.

Peirce, K. \& M. Mcbride (1999), “Aunt Jemima Isn't Keeping Up with the Energizer Bunny: Stereotyping of Animated Spokescharacters in Advertising", Sex Roles a Journal of Research, 40, 959-968.

Philips, B.J. \& B. Gyoeric (1999), “The Cow, The Cook and The Quaker: Fifty Years of Spokes Character Advertising", Journalism and Mass Communication Quarterly, 76(4), 713728.

Phillips, B.J. (1996), "Defining Trade Characters and Their Role in American Popular Culture", Journal of Popular Culture, 29(4), 146-153.

Proctor, D. (2018), Cybernetic Animism: Non-human Personhood and the Internet Digital Existence Ontology, Ethics and Transcendence in Digital Culture ( $1^{\text {st }}$ edt), USA: Taylor \& Francis eBooks.

Rosch, E. et al. (1976), "Basic Objects in Natural Categories", Cognitive Psychology, 8 (3), 382-439.

Shapiro, L. (2004), Something from the Oven: Reinventing Dinnerin 1950's America, New York: Viking Company.

Stafford, R.M. et al. (2013), “A Contingency Approach: The Effects of Spokesperson Type and Service Type on Service Advertising Perceptions", Journal of Advertising, 31(2), 17-35.

Tek, Ö.B. (2004), "Bütünleşik Pazarlama İletişiminde ve Markaların Yerleşiminde Maskotların Rolü ve Önemi”, Pazarlama Dünyası Dergisi, 18(4), 28-32.

Tomasello, M. \& A. Vaish (2013), "Origins of human cooperation and morality", Annu. Rev.

Psychol. 64, 231-255

Uztuğ, F. (2003), Markan Kadar Konuş! Marka İletişimi Stratejileri, İstanbul: Mediacat Yayınları. 